\title{
GENETIC DETERMINANTS OF METABOLIC SYNDROME IN CHILDREN
}

\section{Cherniavska Yu. I., Pokhylko V. I.}

\section{Introduction}

The significant prevalence of obesity and metabolic syndrome in the world over the past two decades has led the WHO to consider overweight as a non-infectious pandemic. In 2017, 22 million children under the age of 5 were overweight in the world, and 155 million between the ages of 5 and $17^{1}$. There was a significant increase in the prevalence of endocrine diseases among children in Ukraine - by $164.4 \%$ according to the Center for Medical Statistics of the Ministry of Health of Ukraine in 2018. Obesity in Ukraine is now observed in 101 thousand children with a maximum in adolescence, up to $20 \%$. In the Poltava region, the prevalence of obesity among children under 13 in 2017 was 1.32 per 10,000 . Almost $60 \%$ of obese adults began to experience overweight problems in childhood and adolescence. In view of this situation, the UN has included indicator 2.2.b "prevalence of overweight among children aged 2 to 4 " in a list of 50 health-related indicators that are monitored and evaluated by an expert group in all countries of the world to determine global progress in achieving the goals of sustainable development ${ }^{2}$

Different definitions of metabolic syndrome stop the development of consensus on diagnostic criteria for childhood. Metabolic syndrome combines metabolic and clinical signs (markers) that can be seen only in the presence of insulin resistance. All components of the metabolic syndrome are long-established medical risk factors for cardiovascular diseases: obesity (excess fat deposits in the abdomen, in the anterior abdominal wall, on the trunk, neck and even on the face - the rarest type of android obesity); insulin resistance (insensitivity of cells to insulin); hyperinsulinemia; type 2 diabetes mellitus; chronic or acute

1 World health statistics 2017: health monitoring for the SDGs, Sustainable Development Goals. P. 76.

2 United Nations Economic and Social Council. Report of the inter-agency and expert group on sustainable development goal indicators. New York: United Nations; [Internet] 2016. [cited 2018 Dec 23]. Available from: http://ggim.un.org/knowledgebase/ KnowledgebaseArticle51479.aspx. 
hypertension; hyperandrogenism in girls; dyslipidemia; violation of normal hemostasis (decrease in fibrinolytic activity of blood); microalbuminuria; hyperuricemia. Experts of the International Diabetes Federation recommend diagnosing metabolic syndrome in children over 10 years of age, taking into account the following criteria: the presence of abdominal obesity, hypertension, hypertriglyceridemia, hyperglycemia and low cholesterol, high density lipoproteins (HDLP). Thus, the diagnosis of metabolic syndrome is established in the case of abdominal obesity (according to the waist circumference) and the other two symptoms listed above. From the age of 15 in boys and 12 in girls, the criteria for waist circumference in adults $(94 \mathrm{~cm}$ and $80 \mathrm{~cm}$, respectively) can be used to determine abdominal obesity. Some researches tried to solve complex and crucial tasks of creating and testing criteria for the diagnosis of metabolic syndrome, there were a number of trials that included testing the diagnostic value of the main components of the metabolic syndrome: waist circumference, systolic and diastolic blood pressure, triglycerides and glucose among boys and girls of 1219 years. According to the main results of the studies, reliable criteria for the diagnosis of metabolic syndrome in children are obesity, hypertension, hyperglycemia, elevated triglycerides and low cholesterol HDL, both for boys and girls ${ }^{33}$. Given that anthropometric parameters in children and adolescents depend on age and sex, percentile tables of body mass index (BMI) of the population according to age and sex were used to diagnose overweight. There is still no consensus on which BMI should be associated with overweight and obesity. Children and adolescents with a BMI in the range between the 85th and 90th percentiles are at risk of developing overweight. Some authors suggest diagnosing overweight / obesity with a BMI equal to the 90th percentile, while others recommend the 95th percentile. Undoubtedly, for the diagnosis of overweight and obesity in children and adolescents it is more appropriate to use standardized BMI criteria taking into account age and sex and body surface area, in this approach the criteria for overweight in adults meet BMI $25 \mathrm{~kg} / \mathrm{m}^{2}$, obesity $-30 \mathrm{~kg} / \mathrm{m}^{2}$ in adults, these parameters are clearly determined, as they determine the high risk of cardiovascular disease. However, BMI does not give a complete picture of the distribution of adipose tissue in the body. There are two main types of adipose tissue distribution in obesity: gynoid and android.

3 Cole T.J. Establishing a standard definition for child overweight and obesity worldwide: international survey. BMJ. 2000. Vol. 320. № 7244. P. 1240-1243. 
The gynoid type is characterized by a predominant accumulation of fat on the thighs, while the android type involves the accumulation of fat in the abdomen. Assessment of insulin resistance should take into account not only the level of insulin, but also compare it with the level of glucose. Hyperinsulinemia on the background of normoglycemia usually indicates the presence of insulin resistance ${ }^{4}$.

There are still no clear criteria for overweight in newborns and young children. Whereas it is extremely important to identify predictors of metabolic syndrome as early as possible. To identify overweight infants according to ICD 10, it is recommended to set 2 codes: P08.0 Overweight child - usually applies to children weighing $4500 \mathrm{~g}$ or more at birth and code P08.1 "Other" heavy "children for gestational age" another fetus or newborn with a large body weight or large for the appropriate gestational age, regardless of gestational age. Typically, this code applies to children weighing more than the 90th percentile for the appropriate gestational age or $4000 \mathrm{~g}$ or more for the appropriate gestational age. However, in recent years, the WHO has recommended the use of body mass index (BMI) to identify overweight infants ${ }^{5}$. Studies to determine the number of overweight babies based on BMI estimates are limited.

Although the pathogenesis of the metabolic syndrome has not been fully studied, insulin resistance and inflammation are thought to be major links. It is suggested that the accumulation of free fatty acids in the liver, adipocytes, skeletal muscle and pancreas in obesity leads to impaired insulin reception and subsequent resistance to it $^{6}$. Insulin resistance in the liver leads to a decrease in its effect on the suppression of glucose production ${ }^{7}$. In addition, hyperinsulinemia causes an increase in the transcription of lipogenic enzyme genes in the liver, leading to increased triglyceride production. It is believed that increased delivery of free fatty acids to the liver leads to insensitivity of the liver to the inhibitory effect of insulin on the secretion of very

\footnotetext{
${ }^{4}$ Fastovets M. M. Metabolic syndrome in children (literature review). Visnyk problem biologii i medytsyny. 2016. № 4 (1). P. 57-61.

World Health Organization. Childhood Overweight Policy Brie[Internet]. 2014; Available from: fhttps:/www.who.int/nutrition/publications/globaltargets2025 policybrief_overweight/en/.

${ }^{6}$ Al-Hamad D, Raman V. Metabolic syndrome in children and adolescents. Transl Pediatr. 2017. № 6(4). P. 397-407. doi:10.21037/tp.2017.10.02.

${ }^{7}$ Wittcopp C, Conroy R. Metabolic Syndrome in Children and Adolescents. Pediatr Rev. 2016 May. № 37 (5). P. 193-202.
} 
low density lipoproteins (LDL) and overproduction of triglyceride-rich LDL particles ${ }^{8}$. Elevated blood pressure in metabolic syndrome is thought to be secondary to hyperinsulinemia through mechanisms such as sympathetic nervous system activity, renal sodium retention, and smooth muscle growth ${ }^{9}$. Insulin has a vasodilating effect on the endothelium, secondary to the production of nitric oxide (a powerful vasodilator $)^{10}$. Endothelial dysfunction and impaired vasodilatation often occur on the background of insulin resistance ${ }^{11}$. Inflammatory cytokines are thought to be released from dysfunctional adipocytes, such as monocytic chemoattractant protein-1 and tumor necrosis factor alpha, promoting macrophage migration to these adipose tissues and further increasing cytokine production. In addition, the decrease in adiponectin levels, which is observed in obesity, can lead to increased inflammation in adipose tissue.

Overweight and obesity are defined as dominant syndromes, along with impaired glucose metabolism, dyslipidemia, and hypertension. A number of studies have shown that overweight / obese children have metabolic disorders, including high levels of circulating levels of triglycerides, insulin, C-peptide, and IL-6 along with low levels of HDL ${ }^{12,13,14}$. Other disorders associated with metabolic syndrome include fatty hepatosis, polycystic ovary syndrome (PCOS), and proinflammatory conditions.

${ }^{8}$ D'Adamo E, Santoro N, Caprio S Metabolic syndrome in pediatrics: old concepts revised, new concepts discussed. Curr Probl Pediatr Adolesc Health Care. 2013 May-Jun. № 43(5). P. 114-23.

9 D'Adamo E, Santoro N, Caprio S Metabolic syndrome in pediatrics: old concepts revised, new concepts discussed. Curr Probl Pediatr Adolesc Health Care. 2013 May-Jun. № 43(5). P. 114-23.

${ }_{10}$ Meshkani R, Adeli K. Hepatic insulin resistance, metabolic syndrome and cardiovascular disease. Clin Biochem. 2009. № 42. P. 1331-46. 10.1016/j.clinbiochem. 2009.05.018.

${ }^{11}$ Wittcopp C, Conroy R. Metabolic Syndrome in Children and Adolescents. Pediatr Rev. 2016. № 37. P. 193-202. 10.1542/pir.2014-0095.

12 Natali A, Ferrannini E. Hypertension, insulin resistance, and the metabolic syndrome. Endocrinol Metab Clin North Am. 2004. № 33. P. 417-29. 10.1016/j.ecl. 2004.03.007.

${ }^{13}$ Balletshofer BM, Rittig K, Enderle MD, et al. Endothelial dysfunction is detectable in young normotensive first-degree relatives of subjects with type 2 diabetes in association with insulin resistance. Circulation. 2000. № 101. P. 1780-4. 10.1161/01.CIR.101.15.1780.

${ }^{14}$ Fraser A, Tilling K, Macdonald-Wallis C. Association of maternal weight gain in pregnancy with offspring obesity and metabolic and vascular traits in childhood. Circulation [Internet]. 2010 Jun. № 121(23). P. 2557-64. Available from: https://www.ncbi.nlm.nih.gov/ pmc/articles/PMC3505019. DOI: 10.1161/CIRCULATIONAHA.109.906081. 
Prevention and treatment of metabolic syndrome can be done through lifestyle modifications, behavioral interventions, pharmacological and surgical interventions as needed.

Epidemiological and experimental evidence confirms that obesity in children and adults is associated with parental health and lifestyle, which may modulate the offspring development program in the periconceptual period, pregnancy, and early childhood. Programming the development of obesity may be the result of changes in genetic expression as an adaptive response of the fetus to adverse intrauterine influences, such as maternal diet or nutritional status during pregnancy. Increasing knowledge about the risk factors involved in the development of obesity in children leads to a better understanding of the etiology of this disorder. It is especially important to identify genetic risk factors that predispose to metabolic syndrome and obesity, this will make it possible to develop new therapeutic strategies and personalized medicine based on molecular diagnostics.

\section{Risk factors of obesity and metabolic disorders}

Among the factors that negatively affect metabolism, lead to its disorders and obesity are genetic, prenatal, food, somatic, psychogenic and others. Not the last role is played by the phenomenon of food imprinting which defines processes of proliferation and differentiation of cells, formation of bodies and systems, their sizes, structure and a functional conditions, activity of enzyme systems, expression of genes encoding enzymes, receptor proteins, determining the nature and direction of metabolic processes, nutrition during the fetal period and the first years of life determines the taste preferences of a person throughout life. A high-calorie and high-fat diet during pregnancy contributes to hypertension and endothelial dysfunction in the unborn child in adulthood. Insufficient or inadequate nutrition of a pregnant woman, infections, smoking, stress, endocrine disorders affect fetal development and cause growth retardation and low birth weight, on the one hand, and changes in metabolic or physiological profile with relevant diseases, on the other $^{15}$. Birth weight is not only a predictor of perinatal health, but

15 Gaillard R, Steegers EA, Duijts L. Childhood cardiometabolic outcomes of maternal obesity during pregnancy: the Generation R Study. Hypertension [Internet]. 2014 Apr. № 63(4). P. 683-91. Available from: https://pubmed.ncbi.nlm.nih.gov/24379180. DOI: 10.1161/HYPERTENSIONAHA.113.02671. 
also psycho-motor development, growth and formation of organs and systems in adulthood. Both low and overweight at birth are associated with an increased risk of obstetric and neonatal complications, as well as metabolic and cardiovascular disorders later in life ${ }^{16,17}$. Excess body mass index (BMI) and weight gain during pregnancy, and especially before childbirth are closely related to obstetric and maternal risks ${ }^{18,19}$. High weight gain during pregnancy is associated with weight gain in the baby at birth and the risk of obesity later in life ${ }^{20,21,22}$. There are also important genetic and environmental factors influencing a baby's birth weight, including genes associated with maternal or infant obesity ${ }^{23}$. Studies of genetic associations have identified several single-nucleotide polymorphisms that link genetic traits to an increased risk of obesity ${ }^{24}$. However, the study of the influence of environmental factors on gene expression to promote the ozogenic phenotype is still insufficient. Epigenetic mechanisms, such as DNA methylation, have been proposed as factors causing

${ }^{16}$ Oostvogels AJ, Stronks K, Roseboom TJ, van der Post JA, van Eijsden M, Vrijkotte TG. Maternal prepregnancy BMI, offspring's early postnatal growth, and metabolic profile at age 5-6 years: the ABCD Study. J Clin Endocrinol Metab. [Internet]. 2014 Oct. № 99(10). P. 3845-54. Available from: https://pubmed.ncbi.nlm.nih.gov/24955609. DOI: $10.1210 /$ jc.2014-1561.

${ }^{17}$ Belmer S.W. Particular issues of food programming: fetal programming. Questions of children's nutrition. 2016. № 14 (1). P. 26-31.(In Russian)

${ }^{18}$ Meas, T., Deghmoun, S., Alberti, C. et al. Independent effects of weight gain and fetal programming on metabolic complications in adults born small for gestational age. Diabetology. 2010. № 53. P. 907-13. https://doi.org/10.1007/s00125-009-1650-y.

${ }^{19}$ Leddy MA, Power ML, Schulkin J. The impact of maternal obesity on maternal and fetal health. Rev Obstet Gynecol. 2008. № 1 (4). P. 170-8.

${ }^{20}$ Rooney B, Schauberger C. Excess pregnancy weight gain and long-term obesity: one decade later. Obstet Gynecol. 2002.№ 100. P. 245-52.

${ }^{21}$ Sahoo K, Sahoo B, Choudhury AK, Sofi NY, Kumar R, Bhadoria AS. Childhood obesity: causes and consequences. J Family Med Prim Care. 2015. № 4 (2). P. 187. DOI: $10.4103 / 2249-4863.154628$.

${ }^{22}$ Lawlor DA, Lichtenstein P, Fraser A, Långström N. Does maternal weight gain in pregnancy have long-term effects on offspring adiposity? A sibling study in a prospective cohort of 146,894 men from 136,050 families. Am J Clin Nutr. 2011 Jul. № 94 (1). P. 142-8.

${ }^{23}$ Rooney B, Schauberger C. Excess pregnancy weight gain and long-term obesity: one decade later. Obstet Gynecol. 2002.№ 100. P. 245-52.

${ }^{24}$ Rampersaud E, Mitchell BD, Pollin TI, Fu M, Shen H, O'Connell JR, Ducharme JL, Hines S, Sack P, Naglieri R, Shuldiner AR, Snitker S. Physical activity and the association of common FTO gene variants with body mass index and obesity. Arch Intern Med. 2008. Sep 8. № 168 (16). P. 1791-7. 
adverse phenotypes ${ }^{25,26}$. Preliminary data suggest that maternalobesity may have asignificant effect on neonatal obesity by altering the DNA methylation of the offspring as a whole by epigenic. It is not yet known how the variability of DNA methylation is affected by interpersonal biological variations, ethnic and gender composition, and specific characteristics of organ and system function ${ }^{23}$. Obesity is determined by the combined effects of genes, the environment, lifestyle and the interaction of these factors ${ }^{27,28}$. Critical periods of obesity are: pregnancy, sudden weight gain, child development (ages 3-6 years), and puberty. Identifying risk factors for obesity from the first days of life and reducing the incidence of obesity in pregnant women and children also have a great impact on the health of adults, preventing complications of this disorder ${ }^{29,30,31}$. Identifying prenatal and environmental factors that affect gene and protein expression through DNA methylation is important to assess the risk of obesity and its adverse effects in newborns. Genetic predisposition to higher BMI or the ratio of waist circumference to hip circumference was associated with changes in cardiometabolic parameters. However, compared to general obesity, central obesity

${ }^{25}$ Rampersaud E, Mitchell BD, Pollin TI, Fu M, Shen H, O'Connell JR, Ducharme JL, Hines S, Sack P, Naglieri R, Shuldiner AR, Snitker S. Physical activity and the association of common FTO gene variants with body mass index and obesity. Arch Intern Med. 2008 Sep 8. № 168 (16). P. 1791-7.

${ }^{26}$ Abdulmalik MA, Ayoub JJ, Mahmoud A, MINA collaborators, Nasreddine L, Naja F (2019) Pre-pregnancy BMI, gestational weight gain and birth outcomes in Lebanon and Qatar: Results of the MINA cohort. PLoS ONE. № 14 (7). e0219248. https://doi.org/ 10.1371/journal.pone.0219248.

${ }^{27}$ Cao-Lei, L., Laplante, D.P. \& King, S. Prenatal Maternal Stress and Epigenetics: Review of the Human Research. Curr Mol Bio Rep. 2016. № 2. P. 16-25 https://doi.org/ 10.1007/s40610-016-0030-x.

${ }^{28}$ Lima RPA, Hayashi DN, Lima KQDF, Gomes NIG, Ribeiro MR, et al. The Role of Epigenetics in the Etiology of Obesity: A Review. J Clin Epigenet. 2017. № 3. P. 41. doi: 10.21767/2472-1158.100075.

29 Abdulmalik MA, Ayoub JJ, Mahmoud A, MINA collaborators, Nasreddine L, Naja F (2019) Pre-pregnancy BMI, gestational weight gain and birth outcomes in Lebanon and Qatar: Results of the MINA cohort. PLOS ONE. № 14 (7). e0219248. https://doi.org/ 10.1371/journal.pone.0219248.

${ }^{30}$ Cao-Lei, L., Laplante, D.P. \& King, S. Prenatal Maternal Stress and Epigenetics: Review of the Human Research. Curr Mol Bio Rep. 2016. № 2. P. 16-25 https://doi.org/ 10.1007/s40610-016-0030-x.

${ }^{31}$ Lima RPA, Hayashi DN, Lima KQDF, Gomes NIG, Ribeiro MR, et al. The Role of Epigenetics in the Etiology of Obesity: A Review. J Clin Epigenet. 2017. № 3. P.41. doi: $10.21767 / 2472-1158.100075$. 
may have a stronger effect on blood glucose and lipid spectrum in children.

As was reminded, obesity and its complications are the result of a combination of lifestyle, genetic and psychological factors. Genetic factors include single nucleotide polymorphism genes that encode regulatory proteins, proinflammatory cytokines involved in the regulation of body composition ${ }^{32,33,34}$. Interestingly, low birth weight is associated with metabolic disorders later in life because these children have a lower proportion of "lean" tissue mass, which provides a greater susceptibility to increased food intake at some point in life ${ }^{35}$.

There are numerous mediators involved in appetite regulation, such as insulin, gastrointestinal peptides (peptide Y, cholecystokinin, glucagonlike peptide-1), ghrelin, which stimulates appetite, leptin, which reduces appetite and increases energy expenditure. Leptin, a hormone synthesized in white adipocytes but also in other organs, controls food intake and energy expenditure through central and peripheral mechanisms. The leptin receptor gene (LEPR) is biologically linked to obesity. During pregnancy, leptin is produced by maternal and fetal adipose tissue, as well as the placenta, with serum umbilical cord leptin levels positively correlated with birth weight compared to maternal leptin levels ${ }^{36,37}$. There are several polymorphisms in the $L E P R$ gene that involved in the mechanism of

${ }^{32}$ Abdulmalik MA, Ayoub JJ, Mahmoud A, MINA collaborators, Nasreddine L, Naja F (2019) Pre-pregnancy BMI, gestational weight gain and birth outcomes in Lebanon and Qatar: Results of the MINA cohort. PLoS ONE. № 14 (7). e0219248. https://doi.org/ 10.1371/journal.pone.0219248.

${ }^{33}$ Cao-Lei, L., Laplante, D.P. \& King, S. Prenatal Maternal Stress and Epigenetics: Review of the Human Research. Curr Mol Bio Rep. 2016. № 2. P. 16-25. https://doi.org/ 10.1007/s40610-016-0030-x.

${ }^{34}$ Lima RPA, Hayashi DN, Lima KQDF, Gomes NIG, Ribeiro MR, et al. The Role of Epigenetics in the Etiology of Obesity: A Review. J Clin Epigenet. 2017. № 3. P. 41. doi: $10.21767 / 2472-1158.100075$.

${ }^{35}$ Sahoo K, Sahoo B, Choudhury AK, Sofi NY, Kumar R, Bhadoria AS. Childhood obesity: causes and consequences. J Family Med Prim Care. 2015. № 4 (2). P. 187-92. doi: $10.4103 / 2249-4863.154628$.

${ }^{36}$ Miller GD. Appetite Regulation: Hormones, Peptides, and Neurotransmitters and Their Role in Obesity. Am J Lifestyle Med. 2017. № 13 (6). P. 586-601. Published 2017 Jun 23. doi: 10.1177/1559827617716376.

${ }^{37}$ Hauguel-de Mouzon S, Lepercq J, Catalano P. The known and unknown of leptin in pregnancy. Am J Obstet Gynecol. 2006. № 194. P. 1537-45. 
obesity, among the most studied single-nucleotide polymorphism Q223R $38,39,40,41,42$.

$G R$ (NR3C1) gene is a glucocorticoid receptor gene located on the short arm of chromosome 5. This ge $\mathrm{n}$ encodes a glucocorticoid receptor, which can function as a transcription factor that binds to elements of the glucocorticoid response in the promoters of genes that respond to glucocorticoids to activate their transcription, and as a regulator of other transcription factors. This receptor is normally present in the cytoplasm, but is transported to the nucleus after ligand binding. It is involved in inflammatory reactions, cell proliferation and differentiation in target tissues. Mutations in this gene are associated with generalized resistance to glucocorticoids. Alternative splicing of this gene leads to variants of transcripts encoding different isoforms. Glucocorticoids act through the glucocorticoid receptor (GR), which makes it an important factor in mediating the effects of cortisol. Although the concentration of glucocorticoids can be measured in plasma, their functional effects on target tissues remain difficult to predict, while individual sensitivity to their effects is probably quite stable. Therefore, we can assume a significant effect of $G R$ gene polymorphism on changes in sensitivity to glucocorticoids and the corresponding remodeling of body composition and metabolic changes ${ }^{43}$.

Many studies in humans and animals have documented the effects of early life experience on neurobiological regulation of stress, susceptibility, mood, and anxiety disorders. Maternal care, family functioning, and infant dysfunction all contribute to neurobiological regulation through epigenetic DNA modification, which is thought to

${ }^{38}$ Pokhilko VI, Tsvirenko SM, Solovyova GO, Chernyavskaya YI Influence of nutrient supply in prenatal and infant age on the development of obesity in children. Suchasna pediatria. 2016. № 7 (79). P. 106-11.(In Ukrainian).

${ }^{39}$ Anderson PM, Butcher KE. Childhood obesity: Trends and potential causes. Future Child. 2006. № 16. P. 19-45.

${ }^{40}$ Miller GD. Appetite Regulation: Hormones, Peptides, and Neurotransmitters and Their Role in Obesity. Am J Lifestyle Med. 2017. № 13 (6). P. 586-601. Published 2017 Jun 23. doi: 10.1177/1559827617716376.

${ }^{41}$ Souren NY, Paulussen AD, Steyls A, et al. Common SNPs in LEP and LEPR associated with birth weight and type 2 diabetes-related metabolic risk factors in twins. Int J Obes (Lond). 2008. № 32. P. 1233-9.

${ }^{42}$ Hauguel-de Mouzon S, Lepercq J, Catalano P. The known and unknown of leptin in pregnancy. Am J Obstet Gynecol. 2006. № 194. P. 1537-45.

${ }^{43}$ Cai G, Cole SA, Butte NF, et al. Genome-wide scan revealed genetic loci for energy metabolism in Hispanic children and adolescents. Int J Obes (Lond). 2008. № 32. P. 579-85. 
be very stable throughout life ${ }^{44}$. It is glucocorticoid receptors that play a central role in modulating the activity of the hypothalamic-pituitaryadrenal system. Some studies have reported an association between early childhood experience and epigenetic modification of $G R$. These studies have shown that the presence of adverse experiences in early childhood, such as maternal depression in the third trimester, parenting disorders, and a history of abuse, are associated with increased methylation of the GR promoter in leukocytes, hippocampus, and placenta. Moreover, the stress at birth exceeds the significance of any other critical life event. Indeed, the effects of preterm birth and postnatal environmental factors, including the need for resuscitation and prolonged physical separation in neonatal intensive care units, may be most adverse during early life. Increased methylation of the $G R$ promoter in leukocytes can lead to decreased regulation of GR cell surface expression, which, in turn, leads to insensitivity of glucocorticoid receptors, the occurrence of proinflammatory reactions ${ }^{45}$. An example of a potentially regulatory $G R$ polymorphism is the BclI polymorphism (rs41423247). Although several studies have analyzed the effects of Bcll polymorphism on body composition and metabolic parameters, somewhat conflicting results have been reported. The BclI polymorphism of the $G R$ gene may affect the weight adjusted for gestational age ${ }^{46}$. The effect of BclI polymorphism realises in the hypersensitivity to glucocorticoids, increased risk of abdominal obesity, depressive disorders, Crohn's disease $^{47,48}$. Individuals homozygous for the G-allele have an increased abdominal circumference, decreased glucose tolerance, elevated

${ }^{44}$ Chagnon YC, Wilmore JH, Borecki IB, et al. Associations between the leptin receptor gene and adiposity in middle-aged Caucasian males from the HERITAGE family study. J Clin Endocrinol Metab. 2000. № 85. P. 29-34.

45 Geelen SS, van Greevenbroek MM, van Rossum EF, Schaper NC, Nijpels G, 't Hart LM, Schalkwijk CG, Ferreira I, van der Kallen CJ, Sauerwein HP, Dekker JM, Stehouwer CD, Havekes B. BclI Glucocorticoid Receptor Polymorphism Is Associated With Greater Body Fatness: The Hoorn and CODAM Studies. J Clin Endocrinol Metab. 2013. 98 (3). E595-E599.

${ }^{46}$ Ibid.

${ }^{47}$ Rosmond R, Holm G.A5 year-follow-up study of 3 polymorphisms in the human glucocorticoid receptor gene in relation to obesity, hypertension, and diabetes. J Cardiometab Syndr. 2008. № 3. P. 132-135.

${ }^{48}$ R. Bertalan, A. Patocs, B. Vasarhelyi et al., Association between birth weight in preterm neonates and the BclI polymorphism of the glucocorticoid receptor gene, Journal of Steroid Biochemistry and Molecular Biology. 2008. Vol. 111. № 1-2. P. 91-94. 
cholesterol and triglycerides. The connection of monozygotic carrier of $\mathrm{C}$-allele and refractory arterial hypotension is revealed ${ }^{49,50,51}$. Carrying the G-allele in preterm infants is associated with a higher risk of having broncho-pulmonary dysplasia ${ }^{52}$.

\section{The influence of $L E P R$ and $G R$ genes polymorphism on the health of mothers with metabolic disorders and their newborn children}

Analysis of $L E P R$ and $G R$ gene polymorphisms among mothers and their newborns can be an important component in the prediction of metabolic disorders and obesity. We conducted a study, the aim of which was to analyze the presence of clinical and genetic determinants of metabolic syndrome in mothers and their newborns.

Materials and methods. We conducted a cross-sectional study of 42 pairs of mothers and newborns treated at the Perinatal Center of Poltava Regional Clinical Hospital, which included the study of their anthropometric, clinical and laboratory parameters and, in particular, 2 types of genetic polymorphisms (LEPR, polymorphism rs1137101 and $G R$, BClI polymorphism). The main group consisted of 15 mother-child pairs, where the woman was clinically obese (BMI (body mass index) more than 30), the comparison group included 27 mother-child pairs, where the woman was overweight (BMI more than 25).

49 Manenschijn L, van den Akker EL, Lamberts SW, van Rossum EF: Clinical features associated with glucocorticoid receptor polymorphisms. An overview. Ann NY Acad Sci. 2009. № 1179. P. 179-198.

${ }^{50}$ Kei Ogasawara, Maki Sato, Koichi Hashimoto, Takashi Imamura, Hayato Go, Mitsuaki Hosoya. A polymorphism in the glucocorticoid receptor gene is associated with refractory hypotension in premature infants. Pediatrics \& Neonatology. 2008. Vol. 59. Issue 3. P. 251-257. https://doi.org/10.1016/j.pedneo.2017.04.007. (http://www. sciencedirect.com/science/article/pii/S187595721730606X.

${ }^{51}$ Geelen SS, van Greevenbroek MM, van Rossum EF, Schaper NC, Nijpels G, 't Hart LM, Schalkwijk CG, Ferreira I, van der Kallen CJ, Sauerwein HP, Dekker JM, Stehouwer CD, Havekes B. BclI Glucocorticoid Receptor Polymorphism Is Associated With Greater Body Fatness: The Hoorn and CODAM Studies. J Clin Endocrinol Metab. March 2013. № 98 (3). E595-E596.

${ }^{52}$ Schreiner C, Schreiner F, Härtel C, Heckmann M, Heep A, Bartmann P, Woelfle J, Müller A, Herting E, Göpel W: Glucocorticoid Receptor Gene Variants and Neonatal Outcome in Very-Low-Birth-Weight Preterm Infants. Neonatology. 2017. № 111. P. 22-29. doi: 10.1159/000446908. 
DNA isolation from dry blood stains was performed using a commercial kit "Quick-DNA Mini Prep Plus Kit" (Zymo Research, USA) according to the protocol "Solid Tissues". To determine the polymorphic variants of $L E P R$ Q223R (668A / G), rs1137101 and GR (NR3C1) BclI $(\mathrm{C}+647 \mathrm{G})$, rs41423247 PCR (polymerase chain reaction) was performed using specific oligonucleotide primers (Metabion, Germany) (Table 1) with the following RFLP reaction (restriction fragment length polymorphism).

Table 1

Sequence of primers for different gene variants

\begin{tabular}{|l|l|}
\hline \multicolumn{1}{|c|}{ Gene variants } & \multicolumn{1}{c|}{ Sequence of primers $\left(\mathbf{5}^{\prime}-\mathbf{3}^{\prime}\right)$} \\
\hline $\begin{array}{l}L E P R Q 223 R \\
(668 \mathrm{~A} / \mathrm{G})\end{array}$ & Forward: ACCCTTTAAGCTGGGTGTCCCAAATAG \\
\cline { 2 - 2 } $\begin{array}{l}\text { GR }(N R 3 C 1) \mathrm{BclI} \\
(\mathrm{C}+647 \mathrm{G})\end{array}$ & Foverse: AGCTAGCAAATATTTTTGTAAGCAATT \\
\cline { 2 - 2 } & Reverse: GCAGTGAACAGTGTACCAGACC \\
\hline
\end{tabular}

The amplification reaction was performed using a commercial kit "Dream Taq Green PCR Master Mix" (Thermo Scientific, USA). The appropriate temperature was provided using an amplifier "Flex Cycler BU" (Analytik Jena, Germany). The amplification products of the $G R$ (NR3C1) and LEPR genes were subjected to hydrolytic cleavage by restriction endonucleases "BclI" and "MspI" (Thermo Scientific, USA), respectively. The restriction reaction was performed in a TDB-120 microthermostat (Biosan, Latvia) for 16 hours at $37^{\circ} \mathrm{C}$ for the LEPR Q223R variant (668A / G) and at $55 \mathrm{C}$ for the GR (NR3C1) BclI variant $(\mathrm{C}+647 \mathrm{G})$. Restriction was stopped for 20 minutes at $80^{\circ} \mathrm{C}$ for both polymorphic variants studied.

Visualization of the restriction fragments was performed in a $2 \%$ agarose gel (agarose "CSL-AG500", Cleaver Scientific Ltd, UK, buffer "10xTVE Electrophoresis Buffer", Thermo Scientific, USA) with the addition of ethidium bromide as a dye. Estimation of the lengths of the restriction fragments was performed by comparison with the molecular weight marker "Gene Ruler 100 bp DNA Ladder" (Thermo Scientific, USA).

Gel images were recorded using a Micro-DOC System with UV Transilluminator Clear View (Cleaver Scientific Ltd, UK). Interpretation 
of the results was performed by visual assessment of the presence or absence of fragments with the appropriate molecular weight (Table 2).

Table 2

Molecular weight of restriction fragments

\begin{tabular}{|l|l|}
\hline \multicolumn{1}{|c|}{ Gene variant } & \multicolumn{1}{c|}{ Size of restriction fragments } \\
\hline LEPR Q223R $(668 \mathrm{~A} / \mathrm{G})$ & $\begin{array}{l}\text { Genotype } A A: 416 \text { p.n. } \\
\text { Genotype } A G: 416,291 \text { and } 125 \text { p.n. } \\
\text { Genotype } G G: 291 \text { and } 125 \text { p.n. }\end{array}$ \\
\hline$G R(N R 3 C 1) \operatorname{BclI}(\mathrm{C}+647 \mathrm{G})$ & $\begin{array}{l}\text { Genotype } C C: 116 \text { p.n., } 90 \text { p.n. } \\
\text { Genotype } C G: 206 \text { p.n.,116 p.n.and } 90 \text { p.n. } \\
\text { Genotype } G G: 206 \text { p.n. }\end{array}$ \\
\hline
\end{tabular}

Figures 1 and 2 show electrophoregrams of the distribution of restriction fragments of polymorphic variants $L E P R$ Q223R $(668 \mathrm{~A} / \mathrm{G})$ and $G R(\mathrm{NR} 3 \mathrm{C} 1) \mathrm{BclI}(\mathrm{C}+647 \mathrm{G})$ in an agarose gel.

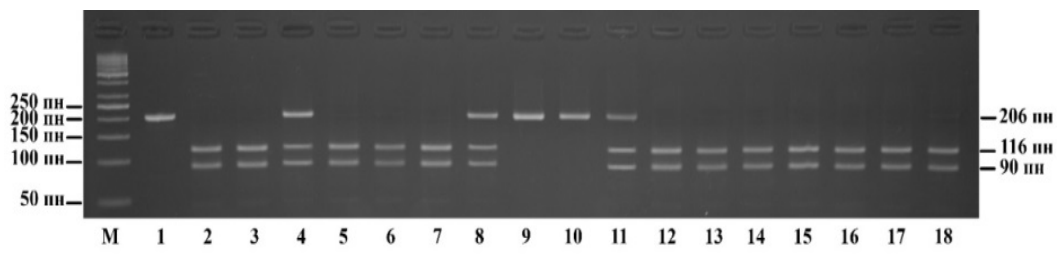

Fig. 1. Electrophoregram of the distribution of restriction fragments of the BcII $(\mathrm{C}+647 \mathrm{G})$ polymorphism of the $G R$ gene (NR3C1)

Note: samples 2-3, 5-7, 12-18 - CC genotype, samples 4, 8, 11 $S G$ genotype, samples 1, 9-10 - GG genotype, $M-$ molecular weight marker, 100 p.n.

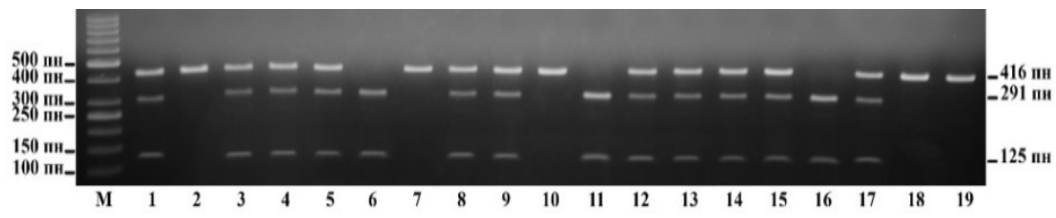

Fig. 2. Electrophoregram of the distribution of restriction fragments of the Q223R polymorphism (668 A / G) of the $L E P R$ gene

Note: samples 2, 7, 10, 18-19-genotype AA, samples 1, 3-5, 8-9, 12-15, 17 - genotype $A G$, samples $6,11,16$ - genotype $G G, M$ - molecular weight marker, 100 p.n. 
Table 3

Stratification of mothers with metabolic disorders and their children by polymorphic variants of the $L E P R$ gene, n (\%)

\begin{tabular}{|c|c|c|c|c|c|c|}
\hline $\begin{array}{c}\text { Geno- } \\
\text { type } \\
\text { variant }\end{array}$ & $\begin{array}{c}\text { Mothers } \\
\text { with } \\
\mathbf{B M I} \geq \mathbf{3 0} \\
\mathbf{( n = 1 5 )}\end{array}$ & $\begin{array}{c}\text { Mothers } \\
\text { with BMI } \\
<\mathbf{3 0} \\
\mathbf{( n = 2 7 )}\end{array}$ & $\mathbf{p}$ & $\begin{array}{c}\text { Newborns } \\
\text { from } \\
\text { mothers } \\
\text { with } \\
\mathbf{B M I} \geq \mathbf{3 0} \\
\mathbf{( n = 1 5 )}\end{array}$ & $\begin{array}{c}\text { Newborns } \\
\text { from } \\
\text { mothers } \\
\text { with } \\
\mathbf{B M I}<\mathbf{3 0} \\
(\mathbf{n = 2 7 )}\end{array}$ & $\mathbf{p}$ \\
\hline $\mathrm{GG}$ & $3(20,0)$ & $5(18,5)$ & 0,911 & $3(20,0)$ & $6(22,2)$ & 0,596 \\
\hline $\mathrm{AG}$ & $7(46,7)$ & $12(44,4)$ & 0,572 & $8(53,3)$ & $11(40,7)$ & 0,322 \\
\hline $\mathrm{AA}$ & $5(33,3)$ & $10(37,0)$ & 0,542 & $4(26,7)$ & $10(37,0)$ & 0,467 \\
\hline
\end{tabular}

Table 4

Stratification of mothers with metabolic disorders and their children by polymorphic variants of the $G R$ gene, $n(\%)$

\begin{tabular}{|c|c|c|c|c|c|c|}
\hline $\begin{array}{c}\text { Geno- } \\
\text { type } \\
\text { variant }\end{array}$ & $\begin{array}{c}\text { Mothers } \\
\text { with } \\
\mathbf{B M I} \geq \mathbf{3 0} \\
(\mathbf{n = 1 5})\end{array}$ & $\begin{array}{c}\text { Mothers } \\
\text { with } \\
\mathbf{B M I}<\mathbf{3 0} \\
(\mathbf{n = 2 7 )}\end{array}$ & $\mathbf{p}$ & $\begin{array}{c}\text { Newborns } \\
\text { from } \\
\text { mothers } \\
\text { with } \\
\mathbf{B M I} \geq \mathbf{3 0} \\
\mathbf{( n = 1 5 )}\end{array}$ & $\begin{array}{c}\text { Newborns } \\
\text { from } \\
\text { mothers } \\
\text { with } \\
\mathbf{B M I}<\mathbf{3 0} \\
\mathbf{( n = 2 7 )}\end{array}$ & $\mathbf{p}$ \\
\hline CC & $10(66,7)$ & $10(37,0)$ & 0,064 & $8(53,3)$ & $13(48,1)$ & 0,500 \\
\hline CG & $4(26,7)$ & $11(40,7)$ & 0,285 & $4(26,7)$ & $12(44,4)$ & 0,466 \\
\hline GG & $1(6,7)$ & $5(18,5)$ & 0,287 & $3(20,0)$ & $2(7,4)$ & 0,235 \\
\hline
\end{tabular}

Statistical processing of the obtained results was performed using the STATA application program package (USA, license number № 71606281563). The mean value (M), standard deviation (SD) were used. Hypotheses about the equality of general means were tested using one-sided and two-sided Student's t-test. The relative values were compared using the criterion $\chi 2$ (chi-square).

At the beginning of the study, we analyzed the associations between individual factors that characterize a woman's somatic condition and obesity. There were no significant differences in somatic status (presence of bad habits, allergic, hereditary, endocrinological, oncological, cardiovascular, skin diseases) among women of the studied groups, except for older women with obesity compared with overweight women $(30.3 \pm 1.0$ years and $26.4 \pm 0.9$ years, respectively, OR $5.195 \% \mathrm{CI}$ $(26.2-29.3), \mathrm{p}=0.008)$. 
In obese mothers, the problem of miscarriage was significantly more common $(\mathrm{p}=0.01$, OR $0.32,95 \%$ CI $(0.02-0.21)$.

The study of the condition of newborns showed that children from obese mothers had significantly higher percentiles of birth weight compared with the control group $(60.9 \pm 7.7$ and $49.75 \pm 4.5$, respectively, $p=0.05$ ). The next step was to determine the frequency of individual variants of genetic polymorphism among 42 women and their children (Tables 3, 4).

As can be seen, the distribution of all three variants of the $L E P R$ and $G R$ gene genotypes among overweight and obese mothers and their children was approximately the same. No association between polymorphic gene variants and obesity in mothers and the distribution of polymorphism variants among their children was found in our study. Although neonatal carriers of the GG and GA genotypes of $L E P R$ have a significantly higher body mass index and the effect of $L E P R$ rs1137101 polymorphism on BMI and birth weight depends on the presence / absence of the dominant $L E P R$ allele in mothers ${ }^{53,54}$.

When we continued to study risk factors for the possible influence of $L E P R$ and $G R$ gene polymorphisms on pregnancy and childbirth in women of the study groups, we found that the GG genotype of the $G R$ gene was associated with a more frequent need for hospitalization $(\mathrm{p}=0.012$, OR 0 , $35,95 \%$ CI (0.04-0.3)), rapid delivery $(\mathrm{p}=0.01$, OR $0.35,95 \%$ CI (0.03$0.25)$ ), umbilical cord entanglement around the neck of the fetus $(p=0.012$, OR $0.3595 \%$ CI $(0.03-0.25))$. The identified associations can be explained by the distorted sensitivity of glucocorticoid receptors to the action of corticosteroids, which is prognostically unfavorable in the process of preparing a woman's hormonal system for delivery.

In a study of the reproductive status of women, it was found that with the GG $L E P R$ genotype, cervical erosion was significantly more common $(\mathrm{p}=0.003$, OR $0.3995 \%$ CI $(0.06-0.31))$. Leptin is known to be a pro-inflammatory cytokine that regulates the maturation of immunocompetent cells and complex intracellular signaling systems

\footnotetext{
${ }^{53}$ Mărginean C, Mărginean CO, Iancu M, Meliţ LE, Tripon F, Bănescu C. The FTO rs9939609 and LEPR rs1137101 mothers-newborns gene polymorphisms and maternal fat mass index effects on anthropometric characteristics in newborns: A cross-sectional study on mothers -newborns gene polymorphisms-The FTO-LEPR Study (STROBE-compliant article). Medicine (Baltimore). 2016. № 95 (49). e5551. doi: 10.1097 / MD.0000000000005551.

${ }^{54}$ Fantuzzi G, Faggioni R. Leptin in the regulation of immunity, inflammation, and hematopoiesis. J Leukoc Biol. 2000 Oct. № 68 (4). P. 437-46.
} 
associated with inflammation, and obese individuals have higher serum leptin concentrations. This fact needs further study in a larger group of patients ${ }^{40}$.

Cardio-metabolic disorders in the form of changes in auscultation of the heart (arrhythmia, functional noise) ( $\mathrm{p}=0.003$ OR $0.39,95 \% \mathrm{CI}$ $(0.06-0.31))$, which can be explained by reduced adaptive capabilities of the cardiovascular system in homozygous carriers of the $\mathrm{G}$ allele of the $G R$ gene ${ }^{37}$. Hence, our study did not identify associations of LEPR and $G R$ gene polymorphism with obesity in mothers and overweight in their children, but revealed an adverse effect of polymorphic variants on obstetric and gynecological features of mothers, delivery and adaptation of infants in the early neonatal period. Further research is needed to determine the risk factors for obesity and the genetic component in the development of cardio-metabolic disorders in order to further implement personalized methods of treatment of children and develop more effective rehabilitation programs.

\section{CONCLUSIONS}

Since the 1970s, very high and increasing rates of overweight and obesity among children, adolescents and adults have been reported in the developed world. In recent years, there have been a number of scientific studies proving the effects of childhood obesity on early and long-term health effects.

A number of trials have shown that overweight/obese children have metabolic disorders, including high levels of circulating levels of triglycerides, insulin, C-peptide, and IL-6 along with low levels of HDL The prevalence of obesity is associated with severe somatic diseases: type 2 diabetes mellitus, hypertension, coronary heart disease, atherosclerosis, cancer and others.

In view of this situation, the $\mathrm{UN}$ has included indicator 2.2.b "prevalence of overweight among children aged 2 to 4 years" in the list of 50 health-related indicators that are monitored and evaluated by an expert group in all countries of the world to determine of global progress towards sustainable development goals.

However, the strict early criteria identifying the development of metabolic syndrome in children are not defined yet. Among the factors that negatively affect the metabolism, lead to its disorders and obesity are genetic, prenatal, food, somatic, psychogenic and others. 
We decided to pay our attention to genetic factors, as the earliest predictors of future metabolism disorders. Analysis of $L E P R$ and $G R$ genes polymorphisms among mothers and their newborns can be an important component in the prediction of metabolic disorders and obesity.

The study did not identify associations of $L E P R$ and $G R$ genes polymorphism with obesity in mothers and overweight in their children, but revealed an adverse effect of polymorphic variants on obstetric and gynecological status of mothers, labor and adaptation of infants in the early neonatal period

\section{SUMMARY}

The significant prevalence of obesity and metabolic syndrome in the world over the past two decades has led the WHO to consider overweight as a non-infectious pandemic. Among the factors that negatively affect the metabolism, lead to its disorders and obesity are genetic, prenatal, food, somatic, psychogenic and others. Analysis of $L E P R$ and $G R$ genes polymorphisms among mothers and their newborns can be an important component in the prediction of metabolic disorders and obesity.

The aim of our study was to analyze the presence of clinical and genetic determinants of metabolic syndrome in mothers and their newborns.

Materials and methods. A cross-sectional study of 42 pairs of mothers and newborns was performed, which included the study of their anthropometric, clinical and laboratory parameters and, in particular, 2 types of genetic polymorphisms (LEPR rs1137101 and GR, BClI polymorphism). The main group consisted of 15 mother-child pairs, where the woman was clinically obese (BMI (body mass index) more than 30), the comparison group included 27 mother-child pairs, where the woman was overweight (BMI more than 25).

Results. Obese mothers were significantly more likely to have a miscarriage $(\mathrm{p}=0.01$, OR $0.32,95 \%$ CI $(0.02-0.21)$. Children from obese mothers had significantly higher percentiles of birth weight compared to control group $(60.9 \pm 7.7$ and $49.75 \pm 4.5$, respectively, $\mathrm{p}=$ $0.05)$. The $G G$ genotype of the $G R$ gene was associated with a more frequent need for hospitalization $(\mathrm{p}=0.012$, OR $0.35,95 \%$ CI $(0.04-$ $0.3)$ ), rapid delivery $(\mathrm{p}=0.01$, OR $0,35,95 \%$ CI $(0.03-0.25))$, umbilical cord entanglement around the neck of the fetus $(\mathrm{p}=0.012$, OR $0.3595 \% \mathrm{CI}(0.03-0.25))$. In children with carriers of the $G G \mathrm{BclI}$ 
genotype $G R$ significantly more often found cardio-metabolic disorders in the form of changes in auscultation of the heart (arrhythmia, functional noise) $(\mathrm{p}=0.003$ OR $0.39,95 \% \mathrm{CI}(0.06-0.31)$.

Conclusion. The study did not identify associations of $L E P R$ and $G R$ genes polymorphism with obesity in mothers and overweight in their children, but revealed an adverse effect of polymorphic variants on obstetric and gynecological status of mothers, labor and adaptation of infants in the early neonatal period.

\section{REFERENCES}

1. World health statistics 2017: health monitoring for the SDGs, Sustainable Development Goals. P. 76.

2. United Nations Economic and Social Council. Report of the interagency and expert group on sustainable development goal indicators. New York: United Nations; [Internet] 2016. [cited 2018 Dec 23]. Available from: http://ggim.un.org/knowledgebase/Knowledgebase Article51479.aspx.

3. Cole T.J. Establishing a standard definition for child overweight and obesity worldwide: international survey. BMJ. 2000. Vol. 320. № 7244. P. 1240-1243.

4. Fastovets M.M. Metabolic syndrome in children (literature review). Visnyk problem biologii i medytsyny. 2016. № 4 (1). P. 57-61.

5. World Health Organization. Childhood Overweight Policy Brie[Internet]. 2014; Available from: fhttps://www.who.int/nutrition/ publications/globaltargets2025_policybrief_overweight/en/.

6. Al-Hamad D, Raman V. Metabolic syndrome in children and adolescents. Transl Pediatr. 2017. № 6(4). P 397-407. doi:10.21037/ tp.2017.10.02.

7. Wittcopp C, Conroy R. Metabolic Syndrome in Children and Adolescents. Pediatr Rev. 2016 May. № 37 (5). P. 193-202.

8. D'Adamo E, Santoro N, Caprio S Metabolic syndrome in pediatrics: old concepts revised, new concepts discussed. Curr Probl Pediatr Adolesc Health Care. 2013 May-Jun. № 43(5). P. 114-23.

9. Meshkani R, Adeli K. Hepatic insulin resistance, metabolic syndrome and cardiovascular disease. Clin Biochem. 2009. № 42. P. 1331-46. 10.1016/j.clinbiochem.2009.05.018.

10. Wittcopp C, Conroy R. Metabolic Syndrome in Children and Adolescents. Pediatr Rev. 2016. № 37. P. 193-202. 10.1542/pir. 2014-0095. 
11. Natali A, Ferrannini E. Hypertension, insulin resistance, and the metabolic syndrome. Endocrinol Metab Clin North Am. 2004. № 33. P. 417-29. 10.1016/j.ecl.2004.03.007.

12. Balletshofer BM, Rittig K, Enderle MD, et al. Endothelial dysfunction is detectable in young normotensive first-degree relatives of subjects with type 2 diabetes in association with insulin resistance. Circulation. 2000. № 101. P. 1780-4. 10.1161/01.CIR. 101.15.1780.

13. Fraser A, Tilling K, Macdonald-Wallis C. Association of maternal weight gain in pregnancy with offspring obesity and metabolic and vascular traits in childhood. Circulation [Internet]. 2010 Jun. № 121(23). P. 2557-64. Available from: https://www.ncbi.nlm.nih.gov/ pmc/articles/PMC3505019. DOI: 10.1161/CIRCULATIONAHA.109. 906081.

14. Gaillard R, Steegers EA, Duijts L. Childhood cardiometabolic outcomes of maternal obesity during pregnancy: the Generation R Study. Hypertension [Internet]. 2014 Apr. № 63(4). P. 683-91. Available from: https://pubmed.ncbi.nlm.nih.gov/24379180. DOI: 10.1161/HYPERTENSIONAHA.113.02671.

15. Oostvogels AJ, Stronks K, Roseboom TJ, van der Post JA, van Eijsden M, Vrijkotte TG. Maternal prepregnancy BMI, offspring's early postnatal growth, and metabolic profile at age 5-6 years: the ABCD Study. J Clin Endocrinol Metab. [Internet]. 2014 Oct. № 99(10). P. 3845-54. Available from: https://pubmed.ncbi.nlm.nih.gov/24955609. DOI: 10.1210/jc.2014-1561.

16. Belmer S.W. Particular issues of food programming: fetal programming. Questions of children’s nutrition. 2016. № 14 (1). P. 26-31. (In Russian)

17. Meas, T., Deghmoun, S., Alberti, C. et al. Independent effects of weight gain and fetal programming on metabolic complications in adults born small for gestational age. Diabetology. 2010. № 53. P. 907-13. https://doi.org/10.1007/s00125-009-1650-y.

18. Leddy MA, Power ML, Schulkin J. The impact of maternal obesity on maternal and fetal health. Rev Obstet Gynecol. 2008. № 1 (4). P. 170-8.

19. Rooney B, Schauberger C. Excess pregnancy weight gain and long-term obesity: one decade later. Obstet Gynecol. 2002. № 100. P. 245-52.

20. Sahoo K, Sahoo B, Choudhury AK, Sofi NY, Kumar R, Bhadoria AS. Childhood obesity: causes and consequences. J Family Med Prim Care. 2015. № 4 (2). P. 187. doi: 10.4103/2249-4863.154628. 
21. Lawlor DA, Lichtenstein P, Fraser A, Långström N. Does maternal weight gain in pregnancy have long-term effects on offspring adiposity? A sibling study in a prospective cohort of 146,894 men from 136,050 families. Am J Clin Nutr. 2011 Jul. № 94 (1). P. 142-8.

22. Rampersaud E, Mitchell BD, Pollin TI, Fu M, Shen H, O'Connell JR, Ducharme JL, Hines S, Sack P, Naglieri R, Shuldiner AR, Snitker S. Physical activity and the association of common FTO gene variants with body mass index and obesity. Arch Intern Med. 2008 Sep 8. № 168 (16). P. 1791-7.

23. Abdulmalik MA, Ayoub JJ, Mahmoud A, MINA collaborators, Nasreddine L, Naja F (2019) Pre-pregnancy BMI, gestational weight gain and birth outcomes in Lebanon and Qatar: Results of the MINA cohort. PLoS ONE. № 14(7). e0219248. https://doi.org/10.1371/ journal.pone.0219248.

24. Cao-Lei, L., Laplante, D.P. \& King, S. Prenatal Maternal Stress and Epigenetics: Review of the Human Research. Curr Mol Bio Rep. 2016. № 2. P. 16-25. https://doi.org/10.1007/s40610-016-0030-x.

25. Lima RPA, Hayashi DN, Lima KQDF, Gomes NIG, Ribeiro MR, et al. The Role of Epigenetics in the Etiology of Obesity: A Review. J Clin Epigenet. 2017. № 3. P. 41. doi: 10.21767/2472-1158.100075.

26. Sahoo K, Sahoo B, Choudhury AK, Sofi NY, Kumar R, Bhadoria AS. Childhood obesity: causes and consequences. J Family Med Prim Care. 2015. № 4 (2). P. 187-92. doi: 10.4103/2249-4863.154628.

27. Pokhilko VI, Tsvirenko SM, Solovyova GO, Chernyavskaya YI Influence of nutrient supply in prenatal and infant age on the development of obesity in children. Suchasna pediatria. 2016. № 7 (79). P. 106-11. (In Ukrainian)

28. Anderson PM, Butcher KE. Childhood obesity: Trends and potential causes. Future Child. 2006. № 16. P. 19-45.

29. Miller GD. Appetite Regulation: Hormones, Peptides, and Neurotransmitters and Their Role in Obesity. Am J Lifestyle Med. 2017. № 13 (6). P. 586-601. Published 2017 Jun 23. doi: 10.1177/ 1559827617716376.

30. Souren NY, Paulussen AD, Steyls A, et al. Common SNPs in LEP and LEPR associated with birth weight and type 2 diabetes-related metabolic risk factors in twins. Int J Obes (Lond). 2008. № 32. P. 1233-9.

31. Hauguel-de Mouzon S, Lepercq J, Catalano P. The known and unknown of leptin in pregnancy. Am J Obstet Gynecol. 2006. № 194. P. 1537-45. 
32. Cai G, Cole SA, Butte NF, et al. Genome-wide scan revealed genetic loci for energy metabolism in Hispanic children and adolescents. Int J Obes (Lond). 2008. № 32. P. 579-85.

33. Chagnon YC, Wilmore JH, Borecki IB, et al. Associations between the leptin receptor gene and adiposity in middle-aged Caucasian males from the HERITAGE family study. $J$ Clin Endocrinol Metab. 2000. № 85. P. 29-34.

34. Geelen SS, van Greevenbroek MM, van Rossum EF, Schaper NC, Nijpels G, 't Hart LM, Schalkwijk CG, Ferreira I, van der Kallen CJ, Sauerwein HP, Dekker JM, Stehouwer CD, Havekes B. BclI Glucocorticoid Receptor Polymorphism Is Associated With Greater Body Fatness: The Hoorn and CODAM Studies. J Clin Endocrinol Metab. 2013.98 (3). E595-E599.

35. Rosmond R, Holm G.A. 5 year-follow-up study of 3 polymorphisms in the human glucocorticoid receptor gene in relation to obesity, hypertension, and diabetes. J Cardiometab Syndr. 2008. № 3. P. 132-135.

36. R. Bertalan, A. Patocs, B. Vasarhelyi et al., Association between birth weight in preterm neonates and the BclI polymorphism of the glucocorticoid receptor gene," Journal of Steroid Biochemistry and Molecular Biology. 2008. Vol. 111. № . 1-2. P. 91-94.

37. Manenschijn L, van den Akker EL, Lamberts SW, van Rossum EF: Clinical features associated with glucocorticoid receptor polymorphisms. An overview. Ann NY Acad Sci. 2009. № 1179. P. 179-198.

38. Kei Ogasawara, Maki Sato, Koichi Hashimoto, Takashi Imamura, Hayato Go, Mitsuaki Hosoya. A polymorphism in the glucocorticoid receptor gene is associated with refractory hypotension in premature infants. Pediatrics \& Neonatology. 2008. Vol. 59. Issue 3. P. 251-257. https://doi.org/10.1016/j.pedneo.2017.04.007. (http://www.sciencedirect. com/science/article/pii/S187595721730606X).

39. Geelen SS, van Greevenbroek MM, van Rossum EF, Schaper NC, Nijpels G, 't Hart LM, Schalkwijk CG, Ferreira I, van der Kallen CJ, Sauerwein HP, Dekker JM, Stehouwer CD, Havekes B. BclI Glucocorticoid Receptor Polymorphism Is Associated With Greater Body Fatness: The Hoorn and CODAM Studies. J Clin Endocrinol Metab. March 2013. № 98 (3). E595-E596.

40. Schreiner C, Schreiner F, Härtel C, Heckmann M, Heep A, Bartmann P, Woelfle J, Müller A, Herting E, Göpel W: Glucocorticoid Receptor Gene Variants and Neonatal Outcome in Very-Low-Birth- 
Weight Preterm Infants. Neonatology. 2017. № 111. P. 22-29. doi: $10.1159 / 000446908$.

41. Mărginean $\mathrm{C}$, Mărginean $\mathrm{CO}$, Iancu $\mathrm{M}$, Meliţ LE, Tripon F, Bănescu C. The FTO rs9939609 and LEPR rs1137101 mothers-newborns gene polymorphisms and maternal fat mass index effects on anthropometric characteristics in newborns: A cross-sectional study on mothersnewborns gene polymorphisms-The FTO-LEPR Study (STROBEcompliant article). Medicine (Baltimore). 2016. № 95 (49). e5551. doi: 10.1097/MD.0000000000005551.

42. Fantuzzi G, Faggioni R. Leptin in the regulation of immunity, inflammation, and hematopoiesis. J Leukoc Biol. 2000 Oct. № 68 (4). P. 437-46.

\title{
Information about the authors:
}

Cherniavska Yu. I.,

Candidate of Medical Sciences, Assistant Professor at the Department of Pediatrics № 1 with Propedeutics and Neonatology Ukrainian Medical Stomatological Academy 23, Shevtchenka str., Poltava, 36000, Ukraine

\author{
Pokhylko V. I., \\ Doctor of Medical Sciences, \\ Professor at the Department of Pediatrics № 1 with Propedeutics and \\ Neonatology \\ Ukrainian Medical Stomatological Academy \\ 23, Shevtchenka str., Poltava, 36000, Ukraine
}

